УДК 164.01:338.242:334.752

DOI: https://doi.org/10.37320/2415-3583/20.5

Дунська А.P.

доктор економічних наук, доцент Національний технічний університет Украӥни «Київський політехнічний інститут імені Ігоря Сікорського» ORCID: https://orcid.org/0000-0002-8623-4507

Шрамко Н.В.

здобувач освітнього ступеня «магістр» Національний технічний університет Украӥни «Київький політехнічний інститут імені Ігоря Сікорського» ORCID: https://orcid.org/0000-0002-5366-202X

\title{
ОСОБЛИВОСТІ ОРГАНІЗАЦІЇ ТА УПРАВЛІННЯ РЕВЕРСИВНОЮ ЛОГІСТИКОЮ ПІДПРИЕМСТВА
}

\begin{abstract}
Стаття присвячена дослідженню та опису ключових особливостей управління та організаиії системи реверсивної логістики на промислових підприємствах України. Питанням розвитку зворотної логістики, систем рециклінгу у сфері промисловості України останнім часом приділяється значна увага. У роботі акцеентується увага на питаннях управління відходами, як однієі із складових зворотної логістики, оскільки недостатня увага окресленим проблемам на українських промислових підприємствах призвела до того, щьо більше 80\% матеріалів відправляються на сміттєві полігони, шо у свою чергу порушує питання екологічності та ефективності використання ресурсів. В зв'язку з иим, вітчизняні науковиі постійно проводять дослідження зворотної логістики в иілому та ї̈ окремих елементів. Результатом роботи вчених, зокрема, являються створення алгоритму управління зворотними матеріальними потоками та виокремлення основних етапів системи рециклінгу відходів підприємства. Важливим елементом ефективної організації реверсивної логістики є безперебійність інформаційного потоку, від достовірності даних в якому значною мірою може залежати ефективність всієї мережі управління відходами. Системи рециклінгу на підприємстві водночас можуть бути спрямовані на мінімізацію відходів як у його внутрішньому середовищі (зменшення виробничих запасів скорочення виробничого ииклу), так $i$ зовнішньому середовищі (налагодження більш тісної комунікаиї між постачальниками, споживачами тощчо). 3 огляду на ие у статті наголошується на необхідності створення інтегрованої системи управління рециклінговими потоками, щзо сприятиме підвищенню ефективності та результативності промислових підприємств.
\end{abstract}

Ключові слова: реверсивна логістика, рециклінг, зворотні потоки матеріальних ресурсів.

Постановка проблеми. Реверсивна логістика сьогодні є одним із найбільш ймовірних і разом з тим недооціненим повною мірою напрямків підвищення загальної ефективності діяльності підприємства. Це обумовлено тим, що часто підприємства стикаються з необхідністю вирішення питань щодо повернення товарів з різних причин. Традиційно логістичні потоки спрямовані на те, що товари рухаються у напряму кінцевого споживача та не повертаються, тому при необхідності організації зворотних логістичних потоків можуть виникати складнощі. При цьому часто зворотні логістичні потоки розглядаються як додаткові фінансові витрати, що має понести підприємство, і не визначається додаткова цінність, яку можна отримати від реверсивної логістики. Це обумовлено тим, що реверсивна розглядається як другорядна логістична функція. Втім при належній організації процесів зворотної логістики, підготовці персоналу, запровадженні контролю запасів та обліку вартості, управління інформаційними потоками та процесу рециклінгу підприємство може отримати не тільки додаткові переваги на ринку, а й перетворити втрати від повернення товарів на отримання додаткового прибутку. 3 огляду на це, вивчення особливостей та конкретизація 
питань управління процесами реверсивної логістики потребують додаткової уваги та поглиблених досліджень.

Аналіз останніх досліджень і публікацій. Особливості зворотної логістики та ключові аспекти управління у цій сфері $є$ предметом досліджень багатьох закордонних та вітчизняних вчених. Серед робіт українських вчених варто відзначити праці С.В. Смерічевської [6], М.Ю. Григорак [2], Л.В. Савченко [2], М.I. Бублика [1], I.M. Кочешкової [3], Н.В. Трушкіної [3], О.А. Цимбалістової [7], С.В. Юденко [7], О.С. Черніхової [7], В.П. Матейчик [4], М. Смешек [4], B.О. Хрутьби [4] та інших.

Проте, в той же час, більшої уваги у контексті наукових досліджень потребують питання ефективної імплементації інструментів зворотної логістики та іiї організація на промислових підприємствах, які мають чимало особливостей.

Мета статті полягає у визначенні основних підходів та характерних елементів організації та управління зворотною логістикою на підприємстві, описі ключових етапів побудови ефективної системи рециклінгу відходів його діяльності.

Виклад основного матеріалу. На сьогоднішній день, майже в кожній сфері підприємництва існує значна конкуренція та боротьба за ринки та клієнтів. Тому будь-які можливості мінімізувати сукупні витрати діяльності, підвищити обсяг створеної доданої цінності в компанії тощо є важливими факторами, які дозволяють втримати наявних споживачів та завоювати лояльність нових. Допомогти досягненню даних цілей в багатьох випадках може вдосконалення системи управління реверсивною логістикою підприємства та забезпечення поглибленої логістичної інтеграції бізнеспроцесів компанії в цілому.

Управління відходами, в свою чергу, являється надзвичайно важливою складовою рециклінгової системи промислового підприємства, оскільки оптимальне управління залишками, що утворилися в результаті завершення певного виробничого циклу також допомагає забезпечити більш ефективне управління фінансовими ресурсами компанії. Крім того, управління відходами дозволяє зменшити можливий негативний вплив діяльності підприємства на стан навколишнього середовища.

Варто зазначити, що ще декілька років тому була створена «Національна стратегія управління відходами в Україні до 2030 року», що має на меті досягнення належного рівня переробки та повторного використання відходів промислового сектору.

Як зазначається у стратегії, в нашій країні до 2030 року планується створити більше 800 нових суб'єктів, що будуть займатися переробкою вторинної сировини, компостуванням та утилізацією біовідходів, що має допомогти зменшити рівень захоронення відходів на полігонах з 95\% до 30\%. Зважаючи на це, питання розвитку зворотної логістики на вітчизняних підприємствах $€$ особливо актуальним, оскільки 3 кожним роком кількість вимог до рівня екологічності виробничих підприємств буде тільки підвищуватися.

В цілому, серед завдань зворотної логістики ключовими являються:

- розробка критеріїв сортування відходів;

- використання спеціалізованих транспортних засобів для транспортування відходів;

- мінімізація витрат на зберігання промислових відходів;

- оптимізація витрат на перевезення відходів від місць їх збору до місць утилізації;

- вторинне використання відходів як pecypcy;

- пошук більш інноваційних технологій поводження з відходами;

- зменшення негативного впливу всіх процесів поводження з відходами як на регіональні екосистеми, так і на навколишнє середовище тощо [8].

Для вдалого виконання наведених вище та багатьох інших завдань, реверсивна логістика послуговується наступними засобами. Це можуть бути, зокрема, переробка, логістичний (в тому числі екологічний) аутсорсинг, екологічний аудит життєвого циклу продукції, реінжиніринг логістичних систем, навчання персоналу, державно-приватне партнерство, венчурне фінансування тощо $є$ одними 3 інструментів реалізації концепції зворотної логістики як такої [8]. 
Як ми бачимо, зворотна логістика включає в себе надзвичайно об' ємну сукупність завдань та засобів їх виконання, що дозволяє імплементувати їі елементи практично у будь-яку сферу діяльності для досягнення позитивного ефекту.

Запровадження системи рециклінгу на промисловому підприємстві може стати відправною точкою як щодо подальшого скорочення сукупних витрат, так і зменшення негативного впливу на зовнішнє середовище з боку компанії.

Щодо цілей, які можуть ставитися перед суб'єктами рециклінгу, то вони в цілому є доволі складними для реалізації, i їх досягнення вимагає співпраці між усіма учасниками процесу поводження 3 відходами і відповідної координації дій. Фахівці в сфері управління ланцюгами поставок вважають, що для ефективної реалізації рециклінгу відходів на підприємстві необхідно вирішувати декілька питань, а саме: як здатність продукту до неодноразового використання може збільшити його вартість; які необхідно створити нові канали в мережі поставок, розподілі і оборотного руху матеріалів; $\mathrm{i}$, в кінцевому результаті, як система рециклінгу буде впливати на вибір матеріалів для виготовлення, пакування, транспортування продукту [4].

Звідси, як ми бачимо, процес організації ефективної системи реверсивної логістики на промисловому підприємстві $€$ доволі складним та багатогранним, тому не дивно, що він може супроводжуватися значною кількістю проблем та особливостей.

Передусім, вдала імплементація засад реверсивної логістики на підприємстві багато в чому залежить від його внутрішнього та зовнішнього середовища. Зокрема, доцільним є створення відповідної логістичної інфраструктури для ефективної реалізації механізмів зворотного логістичного забезпечення, а саме регіональних логістичних центрів поводження 3 відходами, які повинні забезпечувати координацію та партнерство між усіма учасниками логістичного ланцюга (постачальниками, виробників, підприємств збору відходів, споживачів) в єдиному процесі створення споживчої цінності на еколого-економічних засадах.
Тому, при впровадженні основ реверсивної логістики, варто дотримуватися визначених принципів та послідовностей. Узагальнений алгоритм управління зворотними потоками, визначений Цимбалістовою О.А., Юденко Є.В. та Черніховою О.С. відображено на рис. 1. Як ми можемо бачити, базові кроки пропонованого алгоритму не є надто складними, але все ж потребують чіткої координації та безшовної інтеграції з іншими бізнес-процесами підприємства.

Також, Матейчик В.П., Смешек М. та Хрутьба В.О. визначають наступні етапи формування системи рециклінгу відходів підприємства на основі логістичного підходу:

1) вибір стратегії формування системи поводження 3 відходами компанії здійснюється згідно 3 аналізом навколишнього середовища та техніко-економічним аналізом діяльності, яка повинна враховувати основні цілі та задачі підприємства;

2) реалізація логістичних підходів в систему рециклінгу відходів на основі вибраних підсистем;

3) оцінка логістичного потенціалу в системі рециклінгу відходів підприємства;

4) здійснення організаційних змін в загальній структурі управління підприємства;

5) інвентаризація обсягів відходів на кожному етапі виробничого циклу для забезпечення безперебійності виробничого процесу та мінімізації негативного впливу на навколишнє середовище;

6) оцінку ефективності функціонування системи рециклінгу відходів 3 врахуванням логістичних витрат [4].

Звідси, як ми бачимо, вдала організація систем управління реверсивними потоками завжди потребує чіткої взаємодії між різними складовими управління промислового підприємства та постійної поінформованості всіх ланок потоку, зокрема і у зовнішньому середовищі компанії.

Тому не дивно, що серед основних проблем зворотної логістики на промислових підприємствах виділяють відсутність:

- каналів зворотного руху відходів;

-відповідного транспорту для перевезення відходів; 
- Визначення ймовірного обсягу та характеристик реверсивного потоку

- Групування зворотних потоків ресурсів за певним набором характеристик

- Обчислення витрат на повернення матеріальних ресурсів у канали розподілу або їх утилізацію

- Обгрунтування механізму повернення (наприклад використання

4 аутсорсингу тощо)

- Повернення матеріальних ресурсів (їх транспортування, переробка, зберігання)

6 • Ресурсне забезпечення процесів реверсивної логістики

\begin{tabular}{|l|l|}
\hline $\begin{array}{l}\text { - Інформаційне забезпечення зворотного потоку (впровадження відповідної } \\
\text { iнформаційної системи у бізнес-структуру підприємства) }\end{array}$ \\
\hline \\
\hline
\end{tabular}

Рисунок 1 - Алгоритм управління реверсивними потоками

Джерело: [7]

- підприємств 3 переробки відходів та спеціальної техніки, які задовольняли б сучасні екологічні та економічні вимоги;

-інформаційних технологій, що забезпечують ефективну організацію руху в зворотному напрямку або розробка окремих модулів, інтегрованих в наявну інформаційну систему;

- своєчасної та, що важливо, повної інформації щодо зворотного руху відходів;

- фахівців для розробки оптимального руху матеріальних та інформаційних потоків, що дозволять мінімізувати витрати на організацію і роботу каналу [3].

Всі ці проблеми зворотної логістики вимагають комплексного підходу до їх розв'язання, оскільки системи, які будуть будуватися лише 3 урахуванням вдосконалення ревеерсивних потоків, заздалегідь майже повністю приречені на неефек- тивну економію витрат. Дієва система реверсивної логістики повинна включати повне інформаційне забезпечення, тобто постійний збір необхідних даних і їх якісний аналіз [3].

Слід зазначити, що для дійсно ефективної організації алгоритму управління реверсивними потоками особливого значення набуває керування інформаційним потоком, що включає не лише ці дані, але й інформацію про необхідність і можливість використання тих чи інших видів вторинної сировини на підприємствах, наявні місця переробки даної сировини та ії утилізації тощо.

Раціоналізувати процеси реверсивної логістики відходів, мінімізувати обсяги коштів на їх переробку або знищення можливо за рахунок визначених заходів щодо запобігання виникненню відходів чи принаймні зменшення їх обсягу та 
шкідливої дії. Заходи попереджувального характеру також дозволяють усунути або значно зменшити кошти, з якими пов'язані деякі методи утилізації чи знищення відходів. Отже, відповідно до засад раціонального використання відходів профілактичні дії повинні включати:

- мінімізацію відходів;

- попередження виникнення відходів;

- обмеження загального обсягу відходів тощо [3].

Наведені вище заходи $є$ в своїй основі доволі простими та не надто деталізованими, проте все ж являються тим фундаментом, який має стати запорукою вдалого функціонування системи реверсивної логістики на підприємстві.

Варто зауважити, що дійсно вдале та ефективне управління зворотною логістикою є наслідком наявності системи запобігання утворення відходів, що дозволить просто мінімізувати навантаження на реверсивний потік.

За відсутності даної системи зменшення обсягу відходів, не зайвим являється вибір найбільш сучасних та економічно вигідних методів утилізації відходів.

В загальному ж, систему рециклінгу відходів підприємства можна класифікувати як мікрологістичну систему, що пов'язана 3 певним підприємством і призначена для управління потоками в процесі виробництва, постачання та збуту. Залежно від цілей логістичної системи і від рівня її охоплення основних логістичних об'єктів варто виділити наступні види мікрологістичних систем рециклінгу відходів [4]:

1. Внутрішні виробничі системи оптимізують управління матеріальними потоками в межах технологічного циклу (зниження запасів ресурсів і відходів виробничої діяльності, прискорення оберненості оборотного капіталу підприємства, зменшення тривалості виробничого періоду, керування запасами матеріальних ресурсів, оптимізація роботи технологічного транспорту);

2. Зовнішні логістичні системи вирішують задачі, які пов'язані з управлінням матеріальних потоків від їх джерела до пункту призначення поза виробничим технологічним циклом. Це задачі постачання та роз- поділу, такі як раціоналізація руху відходів до підприємства-переробника, скорочення часу доставки відходу як ресурсу чи сировини до споживача, транспортування, складування, вантажопереробка, узгодження цілей постачальників, посередників і споживачів;

3. Інтегровані системи включають елементи внутрішніх виробничих і зовнішніх логістичних систем.

Також, не варто забувати, що на зворотний потік матеріальних ресурсів та на його характеристики може впливати не лише сама логістична система підприємства і ㄲi складові елементи, а й зв'язки між даними складовими. Зокрема, важливими факторами являються взаємодія між ними, відносини у часі та просторі. Зважаючи на це, система реверсивної логістики в компанії повинна мати передусім високий ступінь інтеграції як з іiі внутрішніми бізнес-процесами, так із тенденціями зовнішнього середовища підприємства. Звідси, побудова інтегрованих систем управління зворотними матеріальними потоками являється найбільш вдалим напрямом розвитку багатьох вітчизняних компаній в наш час.

Оцінити ж ефективність створеної чи реорганізованої системи управління зворотними матеріальними потоками можна скориставшись наступними показниками: потужність сукупного оберненого матеріального потоку; логістичні витрати 3 управління зворотним потоком; коефіцієнт економії нових матеріалів від використання зворотного потоку тощо [5].

Саме отримані значення наведених вище показників дозволять повною мірою зрозуміти ефект від змін у системі управління зворотної логістики компанії.

Імплементація інструментів зворотної логістики в діяльність вітчизняних промислових підприємств дозволить звести до мінімуму витрати на процес проходження потоків відходів 3 одночасною підтримкою потрібного рівня екологічної безпеки діяльності компаній, що $є$ однією 3 найважливіших вимог сталого розвитку нашої країни.

Висновки. Необхідність вдалої організації та ефективного управління реверсив- 
ною логістикою на вітчизняних підприємствах являється одним із найважливіших питань для сучасних підприємств в Україні. Передусім, впровадження систем рециклінгу та управління відходами дозволять вітчизняним компаніям значно підвищити власну конкурентоспроможність як на внутрішньому, так і на зовнішньому ринках. До того ж, це позитивно вплине на стан довколишнього середовища, стан якого 3 кожним роком все погіршується.

Наведені в статті алгоритм управління реверсивними потоками та етапи формування системи рециклінгу відходів вказу- ють на необхідність постійної інформаційної підтримки проєктів з удосконалення тих чи інших елементів реверсивної логістики підприємства. Зокрема, це необхідно для чіткої інтеграції зворотних матеріальних потоків з усіма бізнес-процесами компанії. Тому, на нашу думку, саме інтегровані рециклінгові системи являються одним із найголовніших напрямів для подальших досліджень у сфері зворотної логістики, оскільки вони дозволяють по-справжньому досягнути позитивних результатів як для самого підприємства, так і у його зовнішньому середовищі.

\section{Список використаних джерел:}

1. Бублик M.І., Коропецька Т.О. Реверсивна логістика як елемент механізму регулювання техногенних збитків промислових підприємств. Маркетинг та логістика в системі менеджменту : тези доповідей IX Міжнародної науково-практичної конференції (Львів, 8-10 листопада 2012 р.) / Національний університет «Львівська політехніка» [та інші]. Львів : Видавництво Львівської політехніки, 2012. C. 40-42. URL: http://ena.lp.edu.ua:8080/bitstream/ntb/16725/1/24-Bublyk40-42.pdf (дата звернення: 02.11.2021).

2. Григорак М.Ю., Савченко Л.В. Концептуальні основи розвитку реверсивної логістики в циркулярній економіці. Приазовський економічний вісник. 2018. Випуск 5(10). C. 78-84 URL: http://pev.kpu.zp.ua/journals/2018/5_10_uk/15.pdf (дата звернення: 13.11.2021)

3. Кочешкова I.М., Трушкіна Н.В. Реверсивна логістика промислових відходів. Вісник економічної науки України. 2018. № 2. C. 105-108. URL: http://www.venu-journal.org/download/2018/2/19Kocheshkova.pdf (дата звернення: 08.11.2021).

4. Матейчик В.П. Смешек М., Хрутьба В.О. Застосування логістичних підходів в системі поводження з відходами транспортного підприємства. Управління проектами, системний аналіз $i$ логістика. Технічна серія. 2011. Вип. 8. C. 139-144. URL: http://nbuv.gov.ua/UJRN/Upsal_2011_8_38 (дата звернення: 08.11.2021).

5. Мельникова Н.В., Янченко Н.В. Показники оцінки прямого і зворотного матеріальних потоків промислового підприємства. Проблеми і перспективи розвитку підприємниитва. 2018. С. 98-112. DOI: https://doi.org/10.30977/PPB.2226-8820.2018.20.0.98 (дата звернення: 02.11.2021).

6. Смерічевська С.В., Феоктістова Н.О. Концепція реверсивної логістики: сутність і практика застосування на виробничих підприємствах в умовах циркулярної економіки. Dynamics of the development of world science. The 9 th International scientific and practical conference (May 13-15, 2020). Perfect Publishing, Vancouver, Canada. 2020. P. 952-958. URL: https://sci-conf.com.ua/wp-content/ uploads/2020/05/DYNAMICS-OF-THE-DEVELOPMENT-OF-WORLD-SCIENCE_13-15.05.20.pdf (дата звернення: 02.11.2021).

7. Цимбалістова О.А., Юденко Є.В., Черніхова О.С. Проблематика та перспективи розвитку напряму реверсивної логістики в Україні. Економічний простір. № 159. C. 124-129. URL: https://doi.org/10.32782/2224-6282/159-26 (дата звернення: 13.11.2021).

8. Zaloznova Yu., Kwilinski A., Trushkina N. Reverse logistics in a system of the circular economy: theoretical aspect. Економічний вісник Донбасу. 2018. № 4. C. 29-37. URL: http://nbuv.gov.ua/UJRN/ ecvd_2018_4_7 (дата звернення: 02.11.2021).

\section{References:}

1. Bublyk M.I., Koropetska T.O. (2012) Reversyvna lohistyka yak element mekhanizmu rehuliuvannia tekhnohennykh zbytkiv promyslovykh pidpryiemstv [Reversible logistics as an element of the mechanism of regulation of technogenic losses of industrial enterprises]. Marketynh ta lohistyka $v$ systemi menedzhmentu : tezy dopovidei IKh Mizhnarodnoi naukovo-praktychnoi konferentsii (Lviv, 8-10 lystopada 2012 r.) / Natsionalnyi universytet "Lvivska politekhnika" Available at: http: //ena.lp.edu.ua:8080/ bitstream/ntb/16725/1/24-Bublyk40-42.pdf (accessed 02 November 2021). 
2. Hryhorak M.Yu., Savchenko L.V. (2018) Kontseptualni osnovy rozvytku reversyvnoi lohistyky v tsyrkuliarnii ekonomitsi [Conceptual bases of development of reverse logistics in circular economy]. Pryazovskyi ekonomichnyi visnyk, vol. 5, pp. 78-84. Available at: http://pev.kpu.zp.ua/journals/2018/5_10_ uk/15.pdf (accessed 13 November 2021).

3. Kocheshkova I.M., Trushkina N.V. (2018) Reversyvna lohistyka promyslovykh vidkhodiv [Reversible logistics of industrial waste]. Visnyk ekonomichnoi nauky Ukrainy, no. 2, pp. 105-108. Available at: http://www.venu-journal.org/download/2018/2/19-Kocheshkova.pdf (accessed 08 November 2021).

4. Mateichyk V.P., Smeshek M., Khrutba V.O. (2011) Zastosuvannia lohistychnykh pidkhodiv v systemi povodzhennia $\mathrm{z}$ vidkhodamy transportnoho pidpryiemstva [Application of logistic approaches in the waste management system of a transport enterprise]. Upravlinnia proektamy, systemnyi analiz i lohistyka. Tekhnichna seriia, vol. 8, pp. 139-144. Available at: http://nbuv.gov.ua/UJRN/Upsal_2011_8_38 (accessed 08 November 2021).

5. Melnykova N.V., Yanchenko N.V. (2018) Pokaznyky otsinky priamoho i zvorotnoho materialnykh potokiv promyslovoho pidpryiemstva [Indicators for estimating direct and reverse material flows of an industrial enterprise]. Problemy $i$ perspektyvy rozvytku pidpryiemnytstva [Problems and prospects of business development], pp. 98-112. Available at: https://doi.org/10.30977/PPB.2226-8820.2018.20.0.98 (accessed 02 November 2021).

6. Smerichevska S.V., Feoktistova N.O. (2020) Kontseptsiia reversyvnoi lohistyky: sutnist i praktyka zastosuvannia na vyrobnychykh pidpryiemstvakh $\mathrm{v}$ umovakh tsyrkuliarnoi ekonomiky [The concept of reversible logistics: the essence and practice of application in industrial enterprises in a circular economy]. Dynamics of the development of world science. The 9 th International scientific and practical conference. Perfect Publishing, Vancouver, Canada. Pp. 952-958. Available at: https://sci-conf.com.ua/wp-content/ uploads/2020/05/DYNAMICS-OF-THE-DEVELOPMENT-OF-WORLD-SCIENCE_13-15.05.20.pdf (accessed 02 November 2021).

7. Tsymbalistova O.A., Yudenko Ye.V., Chernikhova O.S. Problematyka ta perspektyvy rozvytku napriamu reversyvnoi lohistyky $\mathrm{v}$ Ukraini [Problems and prospects of development of reverse logistics in Ukraine]. Ekonomichnyi prostir, no. 159, pp. 124-129. Available at: https://doi. org/10.32782/2224-6282/159-26 (accessed 13 November 2021).

8. Zaloznova Yu., Kwilinski A., Trushkina N. (2018) Reverse logistics in a system of the circular economy: theoretical aspect. Ekonomichnyi visnyk Donbasu, no. 4, pp. 29-37. Available at: http://nbuv.gov.ua/ UJRN/ecvd_2018_4_7 (accessed 02 November 2021).

\author{
Dunska Alla, Shramko Nazar \\ National Technical University of Ukraine \\ "Igor Sikorsky Kyiv Polytechnic Institute"
}

\title{
FEATURES OF THE ORGANIZATION AND MANAGEMENT OF REVERSE LOGISTICS OF THE ENTERPRISE
}

This article is devoted to the definition and description of key features of management and organization of the reversible logistics system at the enterprises of Ukraine. For a long time, the issue of the development of reverse logistics and recycling systems in the industry of Ukraine is given considerable attention, but there have been no really important changes in this direction as such. Therefore, it is extremely important to determine the necessary vectors of development of domestic companies as soon as possible. Waste management, as one of the components of reverse logistics, requires perhaps the most thorough research, as for a long time this component of reverse logistics did not find the necessary response among the management of Ukrainian enterprises. As a result, we have a huge number of industrial residues, of which more than $80 \%$ of materials are simply sent to landfills. Environmental friendliness of this waste is also a separate topic for research, as the control system for this process is too unreliable and inefficient. In this regard, domestic scientists are constantly conducting research on reverse logistics in general and its individual elements. The result of the scientists' work, in particular, is the creation of an algorithm for the management of reverse material flows and the separation of the main stages of the waste recycling system of the enterprise. Also, one of the main keys to a successful organization of reverse logistics can be called the continuity of information flow, the reliability of the 
data in which may largely depend on the efficiency of the entire waste management network. Having the necessary information about the state of material resources in the distribution channels, the company can take measures to prevent the generation of waste in its activities, such as using these resources in other processes and so on. At the same time, the company's recycling systems can be aimed at minimizing waste both in its internal environment (reduction of production stocks and reduction of the production cycle) and in the external environment (establishing closer communication between suppliers, consumers, etc.). That is, waste management systems can be quite multifaceted and combine components of both environments. In this case, we can talk about the possibility of creating an integrated management system for recycling flows, which will be the most effective and will bring clearer results.

Key words: reverse logistics, recycling, return flows of material resources.

JEL classification: L23, L90, R49, Q32, P48 